\title{
Evaluation of Alkali and Alkaline Earth Metal Cation Selectivities of Lariat Ether Amides by Electrospray Ionization Mass Spectrometry
}

\author{
Sheldon M. Williams and Jennifer S. Brodbelt \\ Department of Chemistry and Biochemistry, The University of Texas at Austin, Austin, Texas, USA
}

Richard A. Bartsch

Department of Chemistry and Biochemistry, Texas Tech University, Lubbock, Texas, USA

\begin{abstract}
Lariat ethers with pendant amide groups have shown promise as new ion sensors because of their selectivity towards particular metal ions. In this study we report alkali and alkaline earth metal binding selectivities of dibenzo-16-crown-5 and fifteen dibenzo-16-crown-5 lariat ether amides (LEAs) as determined by electrospray ionization mass spectrometry (ESI-MS). Additionally, the influence of the acid/base nature of the solution on metal cation selectivity is investigated. The validity of using ESI-MS for determination of selectivities is established by analogous experiments using hosts with known binding constants for the same metal cations and solvent systems. Collisionally activated dissociation (CAD) is used to evaluate the influence of the alkali metal cation binding on the fragmentation of the LEAs. (J Am Soc Mass Spectrom 2003, 14, 1215-1228) (C 2003 American Society for Mass Spectrometry
\end{abstract}

$\mathrm{E}$ lectrospray ionization mass spectrometry (ESIMS) [1-4] has been utilized successfully to analyze of a wide variety of noncovalent complexes [5-7], such as those formed in host-guest chemistry. Numerous recent studies have established that the equilibrium distribution of complexes in solution is reflected in the intensities of host-guest complexes observed in the ESI mass spectra [8-40]. To determine binding selectivities in host-guest chemistry, the intensities of complexes produced by ESI of solutions containing known concentrations of one host and multiple guests are compared. ESI-MS analysis of binding selectivities has several advantages over the more conventional potentiometric, spectrophotometric and NMR titrimetric methods [41], such as reduced sample consumption, tolerance of a wide variety of solvent conditions, and reduced analysis times.

An ESI-MS method for measuring condensed-phase selectivities has been extensively investigated in our laboratory for hosts, such as crown ethers and other macrocycles, with guests like alkali metal, transition metal, heavy metal, and ammonium cations [24-35]. The ESI-MS method is most successful for comparison of host selectivities for a series of similar cations, resulting in the analysis of complexes with similar solvation energies. In these cases, the resulting ESI mass

Published online August 30, 2003

Address reprint requests to Dr. J. S. Brodbelt, Department of Chemistry and Biochemistry, The University of Texas at Austin, 1 University Station A5300, Austin, TX 78712-0165, USA. E-mail: jbrodbelt@mail.utexas.edu spectral distributions of complexes generally agree well with the equilibrium distribution of complexes in solution, allowing the correlation between host structure and selectivity to be investigated. The electrospray efficiencies of ions in ESI-MS are directly related to signal intensities:

$$
\mathrm{I}_{\mathrm{i}}=\mathrm{k}_{\mathrm{i}} \mathrm{C}_{\mathrm{i}}
$$

where $I_{i}$ is the signal intensity for an ion, $k_{i}$ is the electrospray efficiency, and $C_{i}$ is the concentration of the ion in solution. Van Dorsselaer and co-workers established that the electrospray efficiency of an ion is related to its solvation energy [17], and showed that complexes that contain host molecules, such as crown ethers, with guest ions, such as metal ions of the same charge, have similar electrospray efficiencies when experimental conditions are kept constant, resulting in ESI-MS signals which correspond closely in relative intensity to the relative concentrations of the ions in the solution being analyzed. Where solvation energies are significantly different, correction factors can often be determined and applied to achieve a quantitative or semi-quantitative relationship between peak intensities and ion concentrations in solution, as shown in this study. Van Dorssalaer's work also determined that roughly a tenfold decrease in electrospray efficiency is predicted for a $70 \mathrm{~kJ} / \mathrm{mol}$ increase in ion solvation energy [17]. However, even in a highly polar solvent such as water the solvation energies for 222 cryptate with alkali metal ions varied by only $26 \mathrm{~kJ} / \mathrm{mol}$ 

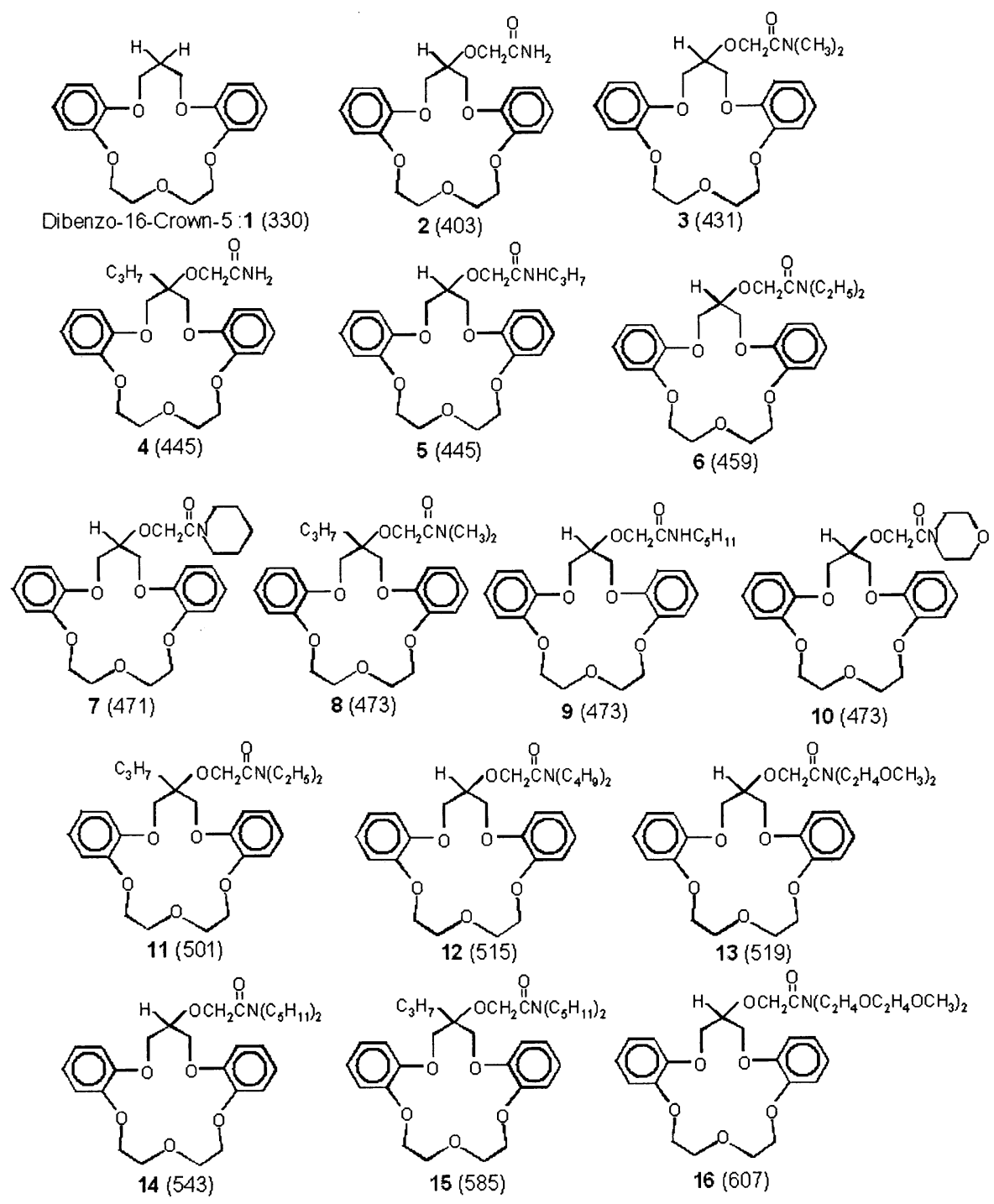

Figure 1. Dibenzo-16-crown-5 and lariat ether amides (molecular weight in Da)

throughout the series of complexes $\left(\mathrm{Li}^{+}\right.$through $\left.\mathrm{Cs}^{+}\right)$ [17]. As the average polarity of the solvent system decreases, one would expect the range of solvation energies to decrease as well. The measurement of gasphase and solution selectivities by mass spectrometry has been reviewed by Schalley [42, 43].

In the present work, ESI-MS is used to analyze the alkali metal binding selectivities of dibenzo-16-crown-5 (1) and the fifteen lariat ether amides (LEAs) 2-16 shown in Figure 1 with several aims. The sensitivity of the ESI-MS method to subtle differences in binding properties of macrocycles that have similar substituents is examined, as well as assessing the ability of ESI-MS to determine $\mathrm{pH}$ dependence on binding selectivities of macrocycles with basic substituents. All fifteen of the LEAs have the same dibenzo-16-crown-5 skeleton, but the substituents attached to the center carbon of the propylene bridge of the crown ether ring differ. One sidearm is an oxyacetamide with substituents ( $R$ and $R^{\prime}$ groups) on the amide nitrogen of varying length and number of oxygen binding sites. The second substituent is either hydrogen or a geminal propyl group. Based on the diameters of the metal cations $\left(\mathrm{Li}^{+}=136 \mathrm{pm}, \mathrm{Na}^{+}\right.$ $=196 \mathrm{pm}, \mathrm{K}^{+}=266 \mathrm{pm}, \mathrm{Rb}^{+}=298 \mathrm{pm}$, and $\mathrm{Cs}^{+}=330$ pm [44]), the cavity diameter of unsubstituted dibenzo15-crown-5 (200 to $240 \mathrm{pm}$ [45]) is expected to be optimal for $\mathrm{Na}^{+}$complexation (Figure 2). The present work focuses on the evaluation of binding selectivities in solution based on ESI-MS results, in contrast to binding properties in the gas phase as studied extensively by Armentrout [46] and Dearden and co-workers $[47,48]$. In a gas-phase environment the relative binding affinities of macrocycles are largely dictated by the charge densities of the metal ions [46-48], whereas in the condensed phase, solvation effects increase the importance of "best fit" considerations, as well as hydrogen bonding and hydrophobic interactions [41].

The ability of lariat ethers to effectively complex metals has led to their development and optimization for use in ion selective electrode membranes [45, 49-54]. 

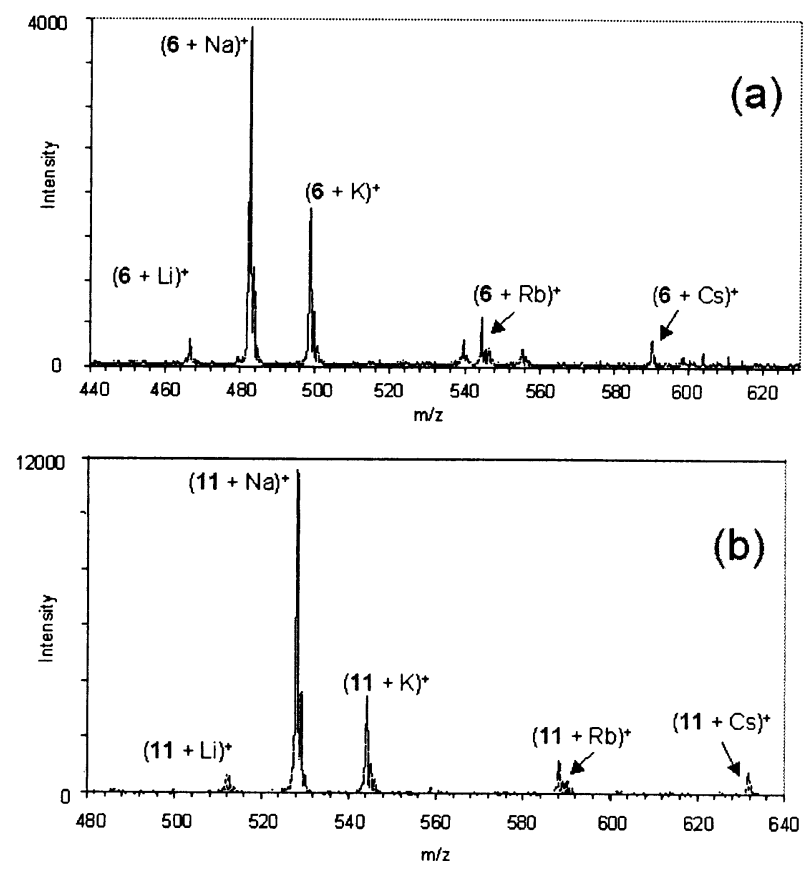

Figure 2. Mass spectra of LEAs with alkali metal chlorides in methanol. (a) 6; (b) 11.

Of the fifteen LEAs shown in Figure 1, 6, 9, 11, 14, and 15 have been investigated previously by conventional methods [51-54]. Bartsch and co-workers incorporated each of these five LEAs into PVC membranes and analyzed their alkali metal cation $\left(\mathrm{Li}^{+}, \mathrm{Na}^{+}\right.$, and $\left.\mathrm{K}^{+}\right)$ selectivities using potentiometry with the fixed interference method in aqueous solutions [55]. Kempen et al. previously investigated four additional LEAs (2, 3, 4, and 8) in methanol using ESI-MS to determine their alkali metal cation selectivities [26]. In the present study, all fifteen LEAs were evaluated in methanolic solutions with alkali metal cations, $\mathrm{Mg}^{2+}$, and $\mathrm{Ca}^{2+}$, and as a function of the acid/base nature of the solution, thus extending the study of lariat ether amide selectivities to solvent systems that are difficult to analyze by potentiometry, but well suited to ESI-MS analysis.

From the potentiometric measurements in aqueous solution by Bartsch and co-workers [51-54], the $\mathrm{Na}^{+} / \mathrm{K}^{+}$selectivity of the LEAs increase in the order: 6 $<9<14<11<15$. The order of increasing $\mathrm{Na}^{+} / \mathrm{Li}^{+}$ selectivity was found to be: $11<15<6<14<9$. For all five LEAs, the order of binding constants was determined to be $\mathrm{Na}^{+}>\mathrm{K}^{+}>\mathrm{Li}^{+}$. Among the conclusions drawn from these results was that the addition of the geminal propyl arm enhanced selectivity for $\mathrm{Na}^{+}$ over $\mathrm{K}^{+}$, but diminished the selectivity for $\mathrm{Na}^{+}$over $\mathrm{Li}^{+}$. In general, the presence of a propyl group geminal to the oxyacetamide substituent encourages optimal pre-organization of the ether amide pendant group over the cavity, enhancing the overall $\mathrm{Na}^{+} / \mathrm{K}^{+}$selectivity and reducing the $\mathrm{Na}^{+} / \mathrm{Li}^{+}$selectivity. However, further lengthening or branching of the geminal arm does not significantly alter selectivity [45, 49-54]. The changes in selectivity observed for geminal arm addition are short range in nature and do not extend significantly beyond the third methylene group. For the host molecules used in these previous studies by the Bartsch group, $\mathrm{Na}^{+} / \mathrm{Rb}^{+}, \mathrm{Na}^{+} / \mathrm{Cs}^{+}, \mathrm{Na}^{+} / \mathrm{Mg}^{2+}$, and $\mathrm{Na}^{+} / \mathrm{Ca}^{2+}$ selectivities were determined only for LEAs 14 and 15 [53]. For $\mathrm{Na}^{+} / \mathrm{Rb}^{+}, \mathrm{Na}^{+} / \mathrm{Cs}^{+}$, and $\mathrm{Na}^{+} /$ $\mathrm{Ca}^{2+}, 15$ always showed a greater selectivity for $\mathrm{Na}^{+}$ than 14, although the $\mathrm{Na}^{+} / \mathrm{Mg}^{2+}$ selectivities of both macrocycles were the same, within experimental uncertainty. The binding constant orderings for $\mathbf{1 4}$ and $\mathbf{1 5}$ were 14: $\mathrm{Na}^{+}>\mathrm{K}^{+}>\mathrm{Rb}^{+}>\mathrm{Cs}^{+}>\mathrm{Li}^{+}>\mathrm{Ca}^{2+}>\mathrm{Mg}^{2+}$ and 15: $\mathrm{Na}^{+}>\mathrm{K}^{+}>\mathrm{Rb}^{+}>\mathrm{Li}^{+}>\mathrm{Cs}^{+}>\mathrm{Ca}^{2+}>\mathrm{Mg}^{2+}$, respectively.

\section{Experimental}

\section{Mass Spectrometry}

All mass spectrometric measurements except the collisionally activated dissociation (CAD) experiments were performed with a Finnigan ion trap mass spectrometer (ITMS) (ThermoFinnigan, San Jose, CA) operated in the mass selective instability mode with modified electronics to allow axial modulation and equipped with an in-house built electrospray source. The electrospray interface was based on a design developed by Oak Ridge National Laboratories (Oak Ridge, TN) with a differentially pumped region containing ion-focusing lenses [56]. Neither a heated desolvation capillary nor a sheath-flow gas were used on the ITMS. For solution deliveries, the syringe pump system (Harvard Apparatus Inc., Holliston, MA) was operated at a flow rate of $2.0 \mu \mathrm{l} / \mathrm{min}$. The ESI needle voltage was $3.4 \mathrm{kV}$. Each spectrum was an average of data from 150 scans. Selectivity versus acidity data were from single experiments, while other mass spectrometry data were averages from three experiments on different days. The MS/MS experiments were performed on a ThermoFinnigan LCQ Duo mass spectrometer. The heated capillary was set at $125^{\circ} \mathrm{C}$ and the sheath gas flow was 20 arbitrary units. The ESI needle voltage was $5.0 \mathrm{kV}$ on the LCQ Duo. Each spectrum was an average of data from 600 scans.

For screening of the alkali and alkaline earth metal cation selectivities of 1-16, solutions containing a single host with multiple metal cations were analyzed. Solutions containing one part of host and two parts of each metal cation were analyzed for each LEA in methanol and methanol/water (3:1, vol/vol). The excess of metal cations relative to the LEA creates a more competitive binding environment for complexation with the host compound. Throughout the study, the concentration of each host was $5.0 \times 10^{-5} \mathrm{M}$ and concentrations of the metal cations were $1.0 \times 10^{-4} \mathrm{M}$, except in the selectivity validation experiments (first section of Results and Discussion), where the concentrations are given. These concentrations were used to ensure solubility of all salts 
Table 1. Distributions for (18-crown-6 + alkaline earth metal cation) complexes

\begin{tabular}{|c|c|c|}
\hline & $\begin{array}{c}\text { Percentage } \\
\left(18-\text { crown-6 }+\mathrm{Mg}^{2+}\right)\end{array}$ & $\begin{array}{c}\text { Percentage } \\
\left(18-\text { crown-6 }+\mathrm{Ca}^{2+}\right)\end{array}$ \\
\hline Calculated distribution from log $\mathrm{K}$ values in solution ${ }^{a}$ & 20 & 80 \\
\hline Distribution from ESI-mass spectrab & 46 & 54 \\
\hline Distribution from ESI-mass spectra with correction for spray efficiencies ${ }^{c}$ & 18 & 82 \\
\hline
\end{tabular}

${ }^{a}$ Calculated using log $\mathrm{K}\left(18-c r o w n-6+\mathrm{Mg}^{2+}\right)=3.61$ and $\log \mathrm{K}\left(18-c r o w n-6+\mathrm{Ca}^{2+}\right)=4.25$ in methanol [59].

${ }^{\mathrm{b}}$ Concentrations were $3 \times 10^{-4} \mathrm{M}$ in $\mathrm{MgCl}_{2}, 3 \times 10^{-4} \mathrm{M}$ in $\mathrm{CaCl}_{2}$, and $5 \times 10^{-5} \mathrm{M}$ in 18-crown-6. Standard deviations were $\pm 8 \%$.

${ }^{\mathrm{c} C o r r e c t i o n s}$ were made by multiplying the uncorrected integrated intensities of (18-crown- $\left.6+\mathrm{Mg}^{2+}\right)$ and $\left(18-\mathrm{crown}^{2} 6+\mathrm{Ca}^{2+}\right)$ by the ratio of signals obtained for the same complexes in solutions of $6 \times 10^{-4} \mathrm{M} \mathrm{MgCl}_{2}: 5 \times 10^{-5} \mathrm{M}$ 18-crown-6 (12:1), and $6 \times 10^{-4} \mathrm{M} \mathrm{CaCl}_{2}: 5 \times 10^{-5} \mathrm{M}_{18-\mathrm{crown}^{-6}}$ (12:1), respectively.

in the solvent while maintaining conditions for increased selectivity versus solutions containing one part of host and one part of each guest metal cation. Concentrations of $\mathrm{H}^{+}$and $\mathrm{OH}^{-}$were set by addition of $\mathrm{HCl}$ or hydroxides of the alkali metal cations. Solutions had nominally neutral $\mathrm{pH}$ values unless otherwise indicated. Metal salts used for these experiments were purchased from Aldrich Chemical Co. (Milwaukee, WI) and used without further purification. The water used was $18 \mathrm{M} \Omega$ that was purified on site. Methanol was Certified A.C.S. Spectranalyzed from Fisher. Ligands 1-16 were synthesized in the laboratories of Professor Richard Bartsch by reported methods [57, 58]. Other chemicals were $99 \%+$ pure from Sigma-Aldrich and used as received. Theoretical values of solution equilibria conditions were obtained using MINEQL+ solution equilibria software, version 4.01 (Environmental Research Software, Hallowell, ME).

\section{Ab Initio Calculations}

Molecular mechanics conformational searches were performed using MMFF (Merck) force fields followed by ab initio calculations using a Restricted Hartree-Fock model at the 3-21G* level of theory with Spartan 2002 PC software (Wavefunction Inc., Irvine, CA) operated on a Gateway PC with an Intel Pentium 4 processor.

\section{Results and Discussion}

\section{Validation of the ESI-MS Method for Determining Selectivities}

Although the validity of determining host-guest selectivities by ESI-MS has been confirmed for macrocycles with alkali and various transition metal cations in numerous earlier studies by this group [24-35], new experiments were performed to assess differences in spray efficiencies for the LEA complexes and to validate this method for investigation of the alkaline earth metal cations, $\mathrm{Mg}^{2+}$ and $\mathrm{Ca}^{2+}$. Since extensive host-guest binding constant data is available in the literature for 18-crown-6 [59], this macrocyclic polyether was used as the model host molecule. For example, the intensities of (18-crown-6 $+\mathrm{Mg}^{2+}$ ) and (18-crown-6 $+\mathrm{Ca}^{2+}$ ) complexes were examined individually to estimate the ESI spray efficiencies, and then mixtures containing 18- crown-6 with both metal species were analyzed and corrected to reflect the solution equilibria. Table 1 compares the relative peak areas of the signals for the different complexes in the ESI mass spectra to the equilibrium distributions calculated in solution using literature binding constants for 18-crown-6 with $\mathrm{Mg}^{2+}$ and $\mathrm{Ca}^{2+}$ in methanol (log $\mathrm{K}$ for $\left(18\right.$-crown-6 $\left.+\mathrm{Mg}^{2+}\right)$ is 3.61 and $\log \mathrm{K}$ for (18-crown-6 $+\mathrm{Ca}^{2+}$ ) is 4.25 [59]). These results show that the relative signal intensities for complexes with these metal cations can be used to semi-quantitatively determine selectivities for solutions with the solvent systems tested. For complexes where relative abundances of the ESI-MS signals deviate from the relative abundances in solution by more than $10 \%$, as is observed for the $\mathrm{Mg}^{2+}$ and $\mathrm{Ca}^{2+}$ complexes, the mass spectral signals must be multiplied by ESI response factors to correct for different electrospray efficiencies of the complexes.

For example, from the ESI-MS signal intensities of the (18-crown-6 $+\mathrm{Mg}^{2+}$ ) and (18-crown-6 $+\mathrm{Ca}^{2+}$ ) complexes for solutions containing just a single metal in excess, it is found that the (18-crown-6 $\left.+\mathrm{Mg}^{2+}\right)$ complexes spray more efficiently than the (18-crown-6 + $\mathrm{Ca}^{2+}$ ) complexes by a factor of nearly four. Thus, the difference in spray efficiencies must be calibrated and normalized by application of appropriate correction factors (i.e., such as dividing the apparent signal intensity of the $\mathrm{Mg}^{2+}$ complex by a factor of nearly four). After analyzing solutions containing 18-crown-6 and both metals and applying the appropriate correction factors, the distribution of $\mathrm{Mg}^{2+}$ and $\mathrm{Ca}^{2+}$ complexes shown in Table 1 agree well with the distribution predicted from the known log $\mathrm{K}$ values.

For the LEA complexes, the three-dimensional cavity effectively solvates the metal cations, thus reducing the variations in spray efficiencies of the different complexes (Table 2). Shown in Table 2 are the relative signal intensities obtained upon ESI-MS analysis of solutions containing one LEA and one metal in excess, with the final column showing the ratio of intensities obtained for the $\mathrm{Mg}^{2+}$ and $\mathrm{Ca}^{2+}$ complexes. This final column, in which the values are close to 1.0, suggests that the spray efficiencies for the LEA/alkaline earth metal complexes are similar, meaning that the correction factors when comparing the $\mathrm{Mg}^{2+} / \mathrm{Ca}^{2+}$ selectivities of the LEAs are minimal. Estimated errors in both mass spectrometri- 
Table 2. Comparisons of distributions of metal cation complexes from mass spectral signal areas

\begin{tabular}{cccc}
\hline LEA & $\begin{array}{c}12: 1 \mathrm{MgCl}_{2}: \mathrm{Host}^{\mathrm{a}} \\
\left(\mathrm{LEA}+\mathrm{Mg}^{2+}\right)\end{array}$ & $\begin{array}{c}12: 1 \mathrm{CaCl}_{2}: \mathrm{Host}^{\mathrm{a}} \\
\left(\mathrm{LEA}+\mathrm{Ca}^{2+}\right)\end{array}$ & $\begin{array}{c}\text { Signal Area Ratio } \\
\left(\mathrm{LEA}+\mathrm{Mg}^{2+}\right) /\left(\mathrm{LEA}+\mathrm{Ca}^{2+}\right)\end{array}$ \\
\hline \hline 4 & 33 & 38 & 0.88 \\
6 & 38 & 39 & 0.98 \\
11 & 40 & 44 & 0.90 \\
14 & 41 & 34 & 1.2 \\
15 & 31 & 26 & 1.17 \\
Average signal area ratio (standard deviation) & & $1.03(0.15)$
\end{tabular}

aLEA concentration is $5 \times 10^{-5} \mathrm{M}$ in methanol; standard deviations of $\pm 8 \%$.

cally determined and theoretically calculated distributions in Tables 1 and 2 are similar, with peak area and literature binding constant uncertainties both at about $\pm 8 \%$ relative error.

\section{Alkali Metal Cation Selectivities}

Examples of ESI-mass spectra obtained for solutions containing LEAs $\mathbf{6}$ and $\mathbf{1 1}$ with the five alkali metals in methanol are shown in Figure 2. The distributions of signal areas were obtained for the alkali metal complexes of 1-16 with two-fold excesses of $\mathrm{LiCl}, \mathrm{NaCl}$, $\mathrm{KCl}, \mathrm{RbCl}$, and $\mathrm{CsCl}$ in methanol. All of the hosts shown in Figure 1 exhibited the same order of alkali metal cation selectivity: $\mathrm{Na}^{+}>\mathrm{K}^{+}>\mathrm{Rb}^{+}>\mathrm{Cs}^{+} \geq \mathrm{Li}^{+}$. The relative percentage of lariat ether bound to $\mathrm{Li}^{+}$, $\mathrm{Rb}^{+}$, or $\mathrm{Cs}^{+}$showed little fluctuation throughout the series of macrocycles, with the intensities ranging from 7 to $14 \%$ for the $\mathrm{Rb}^{+}$complexes, 1 to $8 \%$ for the $\mathrm{Cs}^{+}$ complexes, and 1 to $7 \%$ for the $\mathrm{Li}^{+}$complexes. This selectivity order follows the trend expected from the ionic diameters of the metal cations (diameters given in introduction) versus the inner diameter of the dibenzo16-crown-5 ring (200-240 pm) [44, 45]. Molecular models of LEA 2 with $\mathrm{Na}^{+}, \mathrm{K}^{+}$, and $\mathrm{Rb}^{+}$generated by ab initio calculations show that $\mathrm{Na}^{+}$nests within the plane of the ring, while $\mathrm{K}^{+}$and $\mathrm{Rb}^{+}$perch with their centers outside the plane of the ring (models not shown). $\mathrm{Rb}^{+}$is too large to fit within the three-dimensional cavity formed by the crown ether ring and the pendant oxyacetamide arm and must bind to the side of the polyether ring opposite to this pendant arm.

Since the LEAs show the greatest affinity for $\mathrm{Na}^{+}$ and $\mathrm{K}^{+}$, the $\mathrm{Na}^{+} / \mathrm{K}^{+}$selectivity is plotted in Figure 3 to allow scrutiny of the degree of selectivity as a function of the pendant groups of the lariat ethers. A large degree of variation is seen for the LEAs, with $\mathrm{Na}^{+} / \mathrm{K}^{+}$ values that range from 1.8 to 6.1 , although eleven of the lariat ethers have similar selectivities, in the range of 1.8 to 2.9. Variations in $\mathrm{Na}^{+} / \mathrm{K}^{+}$selectivity are primarily due to the degree of interaction of the pendant arm with $\mathrm{Na}^{+}$and $\mathrm{K}^{+}$[48-54]. Enhancement in the $\mathrm{Na}^{+} / \mathrm{K}^{+}$ selectivity due to the presence of the geminal propyl arm is observed for 4 versus 2, 8 versus 3, 11 versus 6 , and 15 versus 14. The propyl arm is thought to enhance $\mathrm{Na}^{+}$selectivity through steric effects that force the amide-containing pendant arm closer to the center of the cavity of the crown ether ring. The LEAs with the greatest $\mathrm{Na}^{+} / \mathrm{K}^{+}$selectivities are those with hydrogens or methyl groups on the amide nitrogen and a geminal propyl arm, namely 4 and 8 with $\mathrm{Na}^{+} / \mathrm{K}^{+}$selectivities of 4.7 and 6.1, respectively. The effects of geminal or $N, N$-di-substituted alkyl groups of the oxyacetamide pendant arm found in this study support the relative selectivities previously observed by the Bartsch group for LEAs in acidic aqueous solution with ion selective electrodes [52-54]. In methanol, the addition of an oxyacetamide pendant arm with one alkyl group slightly decreases the $\mathrm{Na}^{+} / \mathrm{K}^{+}$selectivity versus that of 1 with no pendant arms. LEAs with $N, N$-di-substituted oxyacetamide pendant arms with short $\mathrm{R}$ groups (1 to 2 methylene units per $\mathrm{R}$ group) show $\mathrm{Na}^{+} / \mathrm{K}^{+}$selectivities similar to those with oxyacetamide pendant arms containing one alkyl group 2 to 5 methylene units in length. When the alkyl groups on the $N, N$-di-substituted amide group reach four to five carbons in length, the $\mathrm{Na}^{+} / \mathrm{K}^{+}$selectivity drops noticeably compared to LEAs with mono-substituted amide groups or those with di-substituted amide groups and shorter alkyl groups. It is surmised that the $N, N$-di-substituted amide decreases $\mathrm{Na}^{+} / \mathrm{K}^{+}$selectivity through steric effects in which the bulky $N, N$-amide substituents force the amide-containing pendant arm farther from the center of the cavity of the crown ether ring, thus reducing the

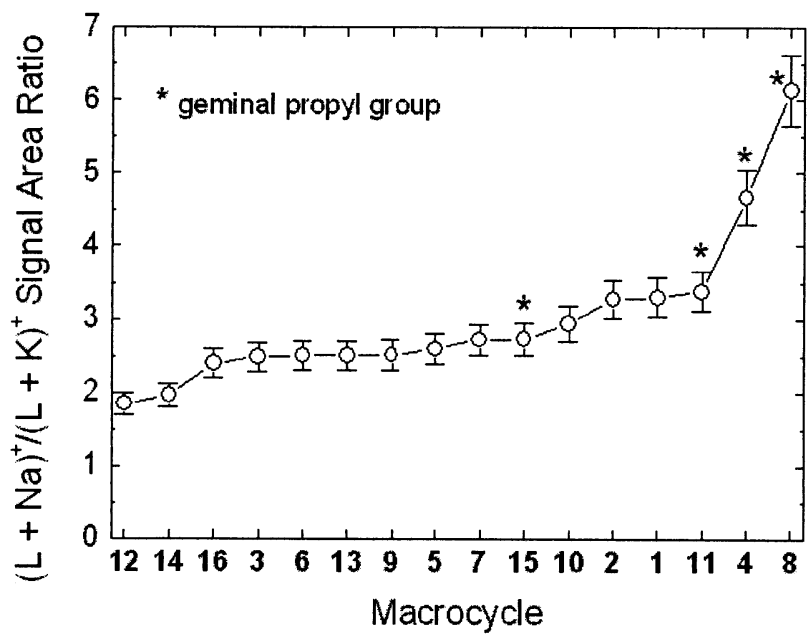

Figure 3. $\mathrm{Na}^{+} / \mathrm{K}^{+}$selectivity ratio of lariat ethers in methanol in order of increasing selectivity $(\mathrm{L}=$ lariat ether). 

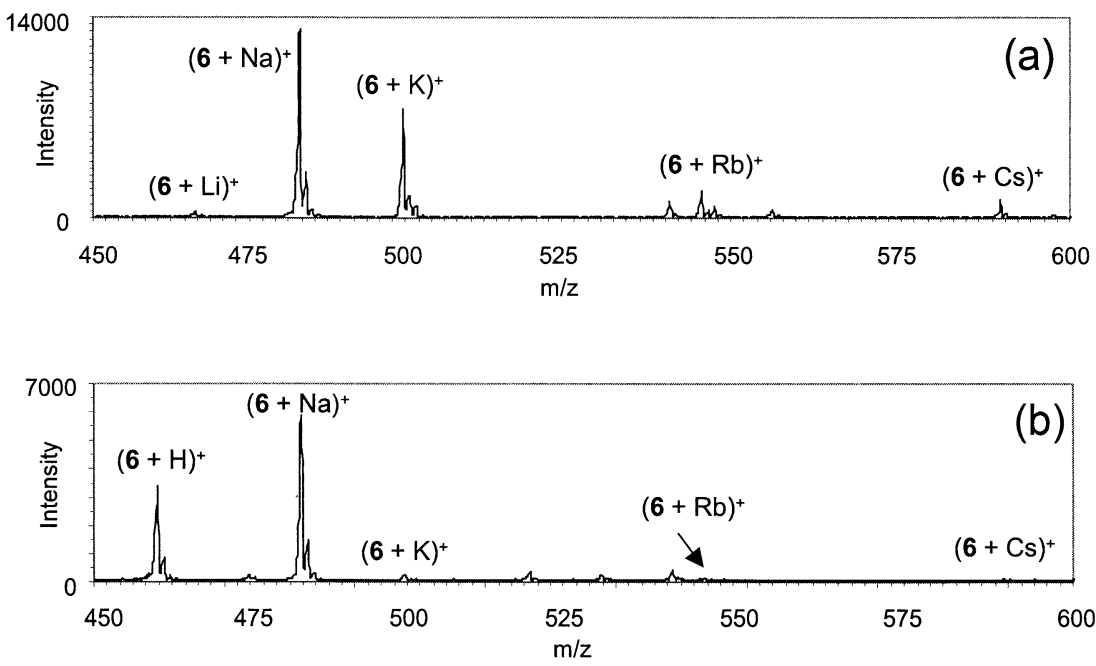

Figure 4. ESI-mass spectra of LEA 6 with alkali metals at various acidities. (a) $\mathrm{p}\left[\mathrm{H}^{+}\right]_{0}=5.0$; (b) $\mathrm{p}\left[\mathrm{H}^{+}\right]_{0}=2.0$.

degree of interaction between the carbonyl oxygen and the metal cation. Substituting an ether oxygen for a methylene group in the $\mathrm{N}, \mathrm{N}$-di-substituted amide (13 versus 12 and 10 versus 6 and 16 versus 14) regains some of the $\mathrm{Na}^{+} / \mathrm{K}^{+}$selectivity lost by the purely hydrocarbon groups because of the nucleophilic attraction of the oxygens for the higher charge density of $\mathrm{Na}^{+}$ versus $\mathrm{K}^{+}$. Ultimately, whether the amide group is mono- or di-substituted does not seem to have a significant impact on $\mathrm{Na}^{+} / \mathrm{K}^{+}$selectivity based on the similar selectivities determined for $\mathbf{9 , 5}$, and $\mathbf{7}$ versus $\mathbf{3}$ and $\mathbf{6}$. Rather, the total number of methylene groups (i.e., steric bulk) attached to the amide nitrogen is the more important factor.

In general, the presence of a geminal propyl group in the LEA significantly enhances the $\mathrm{Na}^{+} / \mathrm{K}^{+}$selectivity, while increasing the number of methylene groups substituted on the amide nitrogen significantly decreases the $\mathrm{Na}^{+} / \mathrm{K}^{+}$selectivity. Thus, the LEAs are versatile and highly "tunable" selectivity agents for $\mathrm{Na}^{+}$versus other alkali metal cations. The overall $\mathrm{Na}^{+} / \mathrm{K}^{+}$selectivity of the LEAs in methanol is observed to be higher than for the lariat ethers with poly(oxa-alkyl) groups that were studied previously by the Brodbelt and Bartsch groups $[33,35]$. The latter were found to have $\mathrm{Na}^{+} / \mathrm{K}^{+}$selectivity values from 0.8 to 4.0 versus 1.8 to 6.1 for the $\mathrm{N}, \mathrm{N}$-dialkyl LEAs.

\section{Effect of Solution Acidity/Basicity on Metal Selectivities}

Because the LEAs may be protonated, the acid/base nature of the solution could play a major role in their binding properties. ESI-MS was used to analyze solutions in which the hydrochloric acid and hydroxide content varied. The notations $\mathrm{p}\left[\mathrm{H}^{+}\right]_{0}$ and $\mathrm{p}\left[\mathrm{OH}^{-}\right]_{0}$ refer to the negative logarithm of the total concentration of $\mathrm{HCl}$ or hydroxide salt added, respectively. Figure 4 shows ESI-mass spectra for LEA 6 at two contrasting acid conditions. A significant shift in the distribution of complexes is observed in Figure 4a and b, with only the $\mathrm{Na}^{+}$complex surviving to a notable extent with the $\mathrm{p}\left[\mathrm{H}^{+}\right]_{0}=2.0$. The variation in $\mathrm{Na}^{+} / \mathrm{K}^{+}$selectivity is summarized in more detail as a function of the $\mathrm{p}\left[\mathrm{H}^{+}\right]_{0}$ for LEA $\mathbf{6}$ and several other LEAs in Figure 5a. An alkali metal cation selectivity order of $\mathrm{Na}^{+}>\mathrm{K}^{+}>\mathrm{Rb}^{+}>\mathrm{Li}^{+}$ with a $\mathrm{Na}^{+} / \mathrm{K}^{+}$selectivity of approximately 2.5 persists in nominally basic $\left(\mathrm{p}\left[\mathrm{OH}^{-}\right]_{0}=3.4\right)$ and neutral $\left(\left[\mathrm{H}^{+}\right]=\right.$ $\left[\mathrm{OH}^{-}\right] \approx 0$ ) solutions. However, in going from nominal $\mathrm{p}\left[\mathrm{H}^{+}\right]_{0}$ values of 5.0 to 3.0 , the $\mathrm{Na}^{+} / \mathrm{K}^{+}$selectivity increases to greater than 4.0 , then increases to $\mathrm{Na}^{+} / \mathrm{K}^{+}$ selectivity values over twenty between $\mathrm{p}\left[\mathrm{H}^{+}\right]_{0}$ values of 2.5 to 2.0. We speculate that in basic and mildly acidic solutions, alkali metal complexation is able to effectively compete with protonation of the oxyacetamide nitrogen due to the conformational pre-organization that occurs because of the close proximity of the amide pendant arm to the metal cation binding macrocyclic cavity of the lariat ether amide, thus favoring metal complexes. As the $\mathrm{p}\left[\mathrm{H}^{+}\right]_{0}$ value progresses to less than 3.0, only $\mathrm{Na}^{+}$, with a size best suited to both the polyether ring cavity diameter and coordination with the amide oxygen over the ring, is able to compete successfully with protonation of the amide nitrogen. Very similar results were obtained for the other LEAs tested $(5,9$, and 14$)$. The $\mathrm{Na}^{+} / \mathrm{K}^{+}$selectivity results obtained as a function of $\mathrm{p}\left[\mathrm{H}^{+}\right]_{0}$ for all four LEAs tested in methanol are shown in Figure $5 \mathrm{a} . \mathrm{Na}^{+} / \mathrm{K}^{+}$selectivities for $\mathbf{6}$ and $\mathbf{1 4}$ in methanol/water $(3: 1, \mathrm{vol} / \mathrm{vol})$ are shown in Figure 5b.

To confirm that the large increase in $\mathrm{Na}^{+} / \mathrm{K}^{+}$selectivity observed for solution acidities with $\mathrm{p}\left[\mathrm{H}^{+}\right]_{0}$ values less than 3.0 was indeed due to a change in binding selectivity rather than an effect of the acidic conditions on the electrospray process, the complexation of 12crown-4 and dibenzo-18-crown- 6 was analyzed as con- 

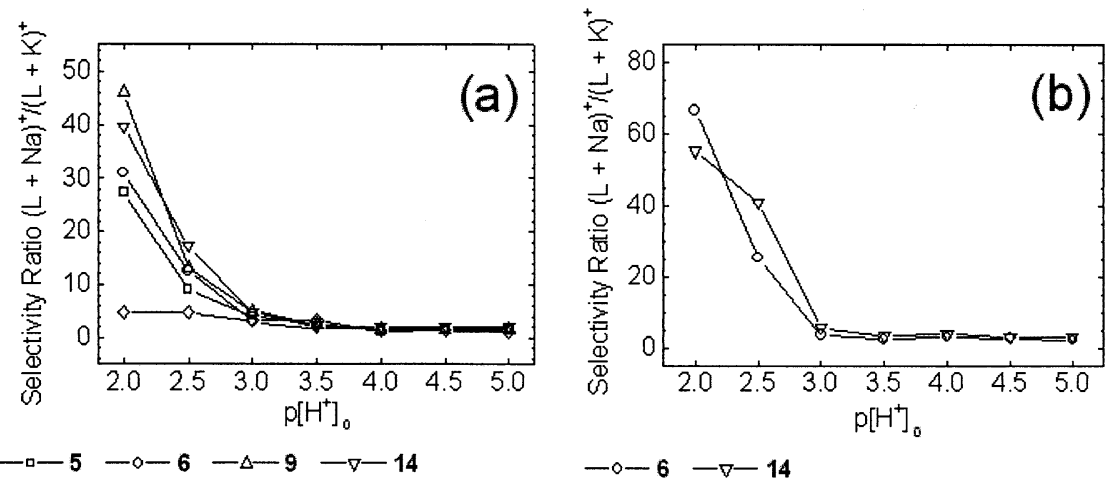

$-\infty 12-$ crown -4
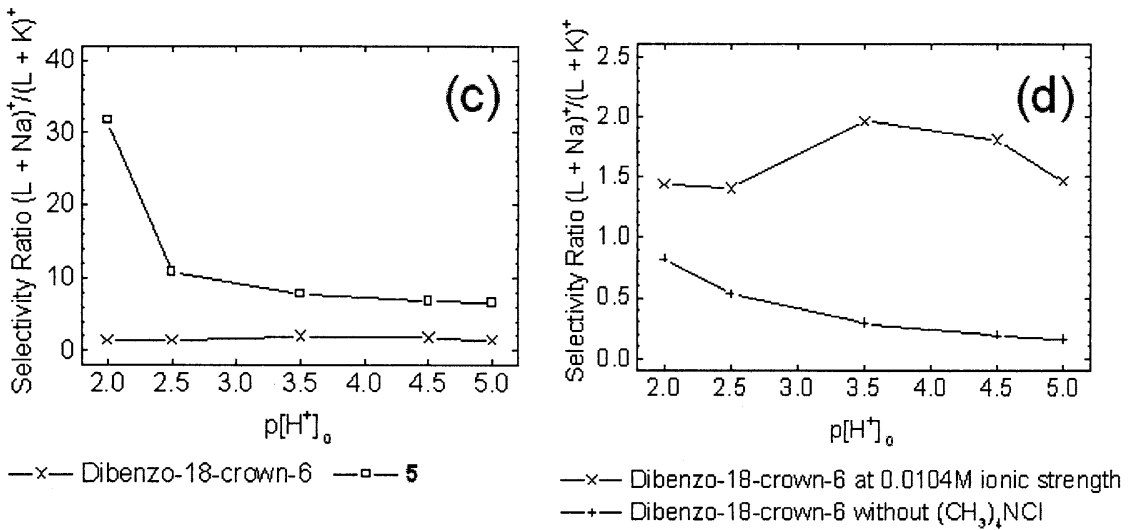

Figure 5. Relative $\mathrm{Na}^{+} / \mathrm{K}^{+}$selectivities of macrocycles versus acidity ( $\mathrm{L}=$ macrocycle). (a) Methanol, (b) methanol/water (3:1, vol/vol); (c) methanol with ionic strength maintained at $0.0104 \mathrm{M}$ with $\left(\mathrm{CH}_{3}\right)_{4} \mathrm{NI}$; (d) methanol with and without ionic strength maintained at $0.0104 \mathrm{M}$ with with $\left(\mathrm{CH}_{3}\right)_{4} \mathrm{NI}$.

trol systems under acidic conditions (Figures 5a and 5c). The degree of change in $\mathrm{Na}^{+} / \mathrm{K}^{+}$selectivity for these two macrocycles from neutral conditions to $\mathrm{p}\left[\mathrm{H}^{+}\right]_{0}=$ 2.0 is very small, with the majority of 12 -crown 4 and dibenzo-18-crown-6 molecules becoming protonated in

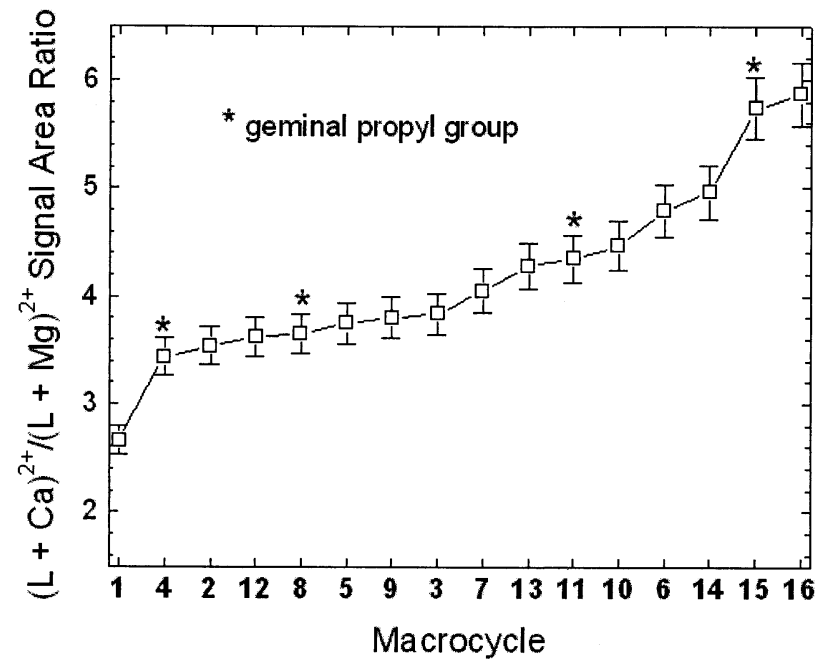

Figure 6. $\mathrm{Ca}^{2+} / \mathrm{Mg}^{2+}$ selectivity of lariat ethers in methanol in order of increasing selectivity $(\mathrm{L}=$ macrocycle). solution and no major shift observed in the preference for complexation of $\mathrm{Na}^{+}$or $\mathrm{K}^{+}$.

In addition, solutions in which the nominal $\mathrm{p}\left[\mathrm{H}^{+}\right]_{0}$ was varied while holding the ionic strength constant were analyzed to evaluate the impact of ionic strength on the $\mathrm{Na}^{+} / \mathrm{K}^{+}$selectivities. The complexation of $\mathbf{5}$ and dibenzo-18-crown- 6 were both tested at $\mathrm{p}\left[\mathrm{H}^{+}\right]_{0}$ values of 5.0, 4.0, 3.5, 2.5, and 2.0 with tetramethylammonium iodide present at concentrations necessary to maintain a constant ionic strength of $0.0104 \mathrm{M}$. As the acid content of the solution is increased, a large increase in $\mathrm{Na}^{+} / \mathrm{K}^{+}$ selectivity from six to greater than twenty still occurs for 5, while the $\mathrm{Na}^{+} / \mathrm{K}^{+}$selectivity of dibenzo-18crown-6 remains constant at about 1.6 (Figure 5c). This is supporting evidence that the observed change in $\mathrm{Na}^{+} / \mathrm{K}^{+}$selectivity of the LEAs results from a change in their chemical properties rather than an artifact of the electrospray process. The effect is presumably due to the preferential protonation of the amide nitrogen over complexation of $\mathrm{Li}^{+}, \mathrm{K}^{+}$, or $\mathrm{Rb}^{+}$, with an effective competition between protonation and metal cation complexation only for $\mathrm{Na}^{+}$, the metal cation that is most strongly bound.

Note that artificially increasing the ionic strength, as done for the experiments whose results are illustrated in Figure 5c, may also cause an impact on the observed 
selectivities of the macrocycles. This effect is related to the mechanism of the ESI process and the suppression or enhancement of specific ions emerging from the spray due to their surface activities. For example, adding the trimethyl ammonium chloride to the solutions of the alkali metal chlorides with dibenzo-18-crown-6 causes a consistent increase in the $\mathrm{Na}^{+} / \mathrm{K}^{+}$selectivities relative to those observed for solutions in which the auxiliary electrolyte was not added, as illustrated in Figure 5d.

It should be noted that during the electrospray process, the acidity of the emerging droplets will be altered relative to that of the bulk solution due to the evaporation of solvent and $\mathrm{HCl}$ from the electrospray droplets and proton generation due to electrochemical processes [60-66]. Faster evaporation of the solvent relative to that of $\mathrm{HCl}$ would mean that the total concentration of protonated species in the droplets would increase with time. According to Cook and co-workers, the decrease in the $\mathrm{pH}$ of aqueous solution droplets, initially at $\mathrm{pH} 6.89$, at $2.0 \mathrm{~mm}$ from the ESI needle tip with a $+3.5 \mathrm{kV}$ needle voltage is about 0.60 $\mathrm{pH}$ units [60]. Similar results were reported by Wang and Agnes in which the gas-phase concentrations of EDTA-metal ion complexes generated by ESI-MS from an aqueous solution at a needle voltage of $-3.2 \mathrm{kV}$ were found to exist at concentrations resembling those expected for solution acidities less than a $\mathrm{pH}$ unit higher than bulk solution from $\mathrm{pH} 5$ to 8 [61]. However, at pH values lower than 5 and higher than 8 , the EDTA-metal complexes in the gas-phase were present at concentrations nearly identical to the bulk solution, showing the ESI process had no significant influence on EDTA-metal concentrations [61]. Also, it should be considered that even though the ESI process may increase the acidity of the droplet environment, the metal ion concentration will also increase as the solvent evaporates from droplets. Taking all of these influences during the ESI process into consideration, the increase in proton concentration due to solvent evaporation should be balanced in part by a simultaneous increase in metal salt concentration and generation of protons in the methanolic solutions by the electrochemical reactions of ESI. The ESI-MS method seems to be an effective way to rapidly screen acid/base effects on the $\mathrm{Na}^{+} / \mathrm{K}^{+}$selectivities of macrocycles, while conventional potentiometric methods can be reserved for more quantitative studies of the most relevant macrocycles as identified by the initial ESI-MS evaluation.

Based on the results shown in Figures 4 and 5, the LEAs are found to become highly $\mathrm{Na}^{+}$selective under moderately acidic solution conditions $\left(\mathrm{p}\left[\mathrm{H}^{+}\right]_{0}<3.0\right)$. Even in competition with proton binding, $\mathrm{Na}^{+}$is still able to maintain a stable complex involving the lariat ether through interaction with the carbonyl oxygen of the amide and the oxygen atoms of the macrocyclic ring. $\mathrm{K}^{+}$is too large to interact well with the amide oxygen, and the protonation of the amide nitrogen is preferred over $\mathrm{K}^{+}$complexation. It appears that $\mathrm{Na}^{+}$is
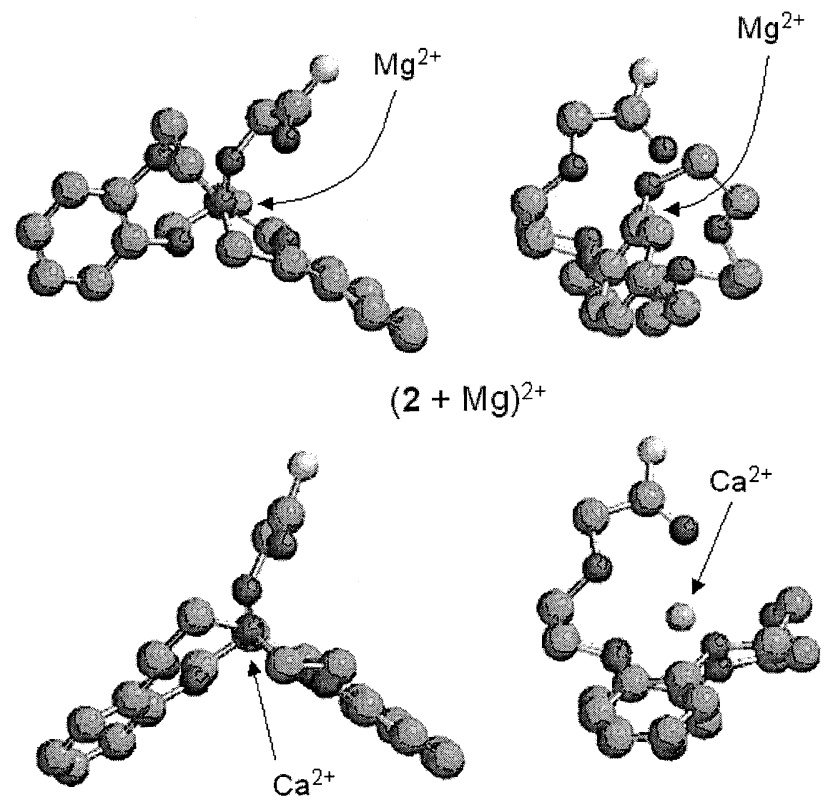

$(2+\mathrm{Ca})^{2+}$

Figure 7. Ab initio molecular models of 2 with $\mathrm{Mg}^{2+}$ and $\mathrm{Ca}^{2+}$ ions. Black $=$ oxygen, gray $=$ carbon, light gray $=$ nitrogen, hydrogens omitted for clarity. Models on the left and right are rotated $90^{\circ}$ around their vertical axis.

able to maintain interaction with the lariat ether to a greater degree than the other alkali metal cations in the presence of the amide nitrogen protonation equilibrium due to the higher association constant for $\mathrm{Na}^{+}$. The LEAs have a small variation in $\mathrm{Na}^{+} / \mathrm{K}^{+}$selectivity in solutions of low to moderate acidities, which is a valuable property in ion selective electrodes. They also show structural stability and a large shift to higher $\mathrm{Na}^{+} / \mathrm{K}^{+}$selectivities at high acidities.

\section{Alkaline Earth Metal Cation Selectivities}

In a manner similar to that described for the experimental determination of the alkali metal cation selectivities, ESI-MS was used to evaluate the selectivities for the alkaline earth metal cations, $\mathrm{Mg}^{2+}$ and $\mathrm{Ca}^{2+}$. The range in variation observed for the $\mathrm{Ca}^{2+} / \mathrm{Mg}^{2+}$ selectivities (i.e., 3 to 6 ) of the LEAs is similar to the range observed for the $\mathrm{Na}^{+} / \mathrm{K}^{+}$selectivities (2 to 6). $\mathrm{Ca}^{2+} / \mathrm{Mg}^{2+}$ selectivity appears to be largely related to the overall size of the LEA. The general selectivity preference of the LEAs towards complexation with $\mathrm{Ca}^{2+}$ rather than $\mathrm{Mg}^{2+}$ can be understood in part because of the ionic radii of the cations. Figure 7 shows ab initio molecular models of 2 complexed with $\mathrm{Mg}^{2+}$ and $\mathrm{Ca}^{2+}$. The much smaller radius of $\mathrm{Mg}^{2+}$ compared to $\mathrm{Ca}^{2+}$ (78 and $106 \mathrm{pm}$, respectively [44]) requires significant distortion of the macrocyclic ring to attain a stable complex. However, the $\mathrm{Ca}^{2+}$ radius is only $6 \%$ larger than that of $\mathrm{Na}^{+}$, so the size of $\mathrm{Ca}^{2+}$ is still quite a good fit for the three dimensional cavity of the LEA.

The geminal propyl arm present on 4, 8, 11, and 15 
has much less impact on selectivity with the alkaline earth metals than was observed with the alkali metals. The ionic radii of $\mathrm{Na}^{+}, \mathrm{Mg}^{2+}$, and $\mathrm{Ca}^{2+}$ are much smaller than the ionic radius of $\mathrm{K}^{+}$. Thus, although the diameter of $\mathrm{K}^{+}$is significantly larger than the diameter of the 16-crown-5 ring of the lariat ethers, the diameters of the other three ions are all small enough to nest within the lariat ether ring cavity. The geminal arm affects selectivity via steric effects which position and effectively decrease the distance between the amide containing pendant arm and the center of the crown ether ring cavity. Ions of ionic radii much larger than $\mathrm{Ca}^{2+}$ will be excluded to a significant extent because of a poorer fit in the resulting cavity of smaller volume. As a result, structural changes made directly to the amide containing pendant arm become more significant.

The increase in $\mathrm{Ca}^{2+} / \mathrm{Mg}^{2+}$ selectivity with increasing size or mass of the lariat ether likely involves several factors. Because the alkaline earth dications have over twice the charge density of their corresponding alkali metal cations, polar solvent molecules with large dipole moments more readily displace the fairly non-polar pendant groups from binding $\mathrm{Mg}^{2+}$. Also, the different charge densities of the metal ions influence the degree to which the larger substituents on the amides interact with the relatively non-polar crown ether ring, the benzo-rings, and the solvent. When a LEA is complexed with $\mathrm{Na}^{+}$or $\mathrm{K}^{+}$, the larger alkyl groups may have hydrophobic interactions with the less polar crown ether and benzo-rings in preference to the highly polar methanol solvent, and will do so more favorably with $\mathrm{K}^{+}$due to its lower charge density. Conversely, when the LEAs are complexed with $\mathrm{Mg}^{2+}$ or $\mathrm{Ca}^{2+}$, the higher charge density of these dications may decrease this tendency for interaction of the alkyl amide substituent with the macrocycle, causing the alkyl groups to be preferentially solvated and pulling the oxyacetamide pendant arm away from the crown ether ring. Therefore, the LEAs with larger substituents will favor $\mathrm{Ca}^{2+}$ complexation over $\mathrm{Mg}^{2+}$.

\section{Collisionally Activated Dissociation of the Lariat Ether Complexes}

Collisionally activated dissociation (CAD) experiments were undertaken for the alkali metal complexes with seven of the macrocycles to evaluate the fragmentation pathways as a function of the type of metal cation bound to the macrocycle, with comparison to the fragmentation patterns of the protonated macrocycles. Representative spectra are shown in Figures 8, 9, 10 for three protonated, $\mathrm{Li}^{+}$-cationized, and $\mathrm{K}^{+}$-cationized lariat ethers. CAD results for the protonated LEAs are summarized in Table 3. Structures that fit many of the observed $\mathrm{m} / \mathrm{z}$ values of the fragment ions are proposed in Scheme 1. Several common fragment ions are observed upon CAD of the protonated lariat ethers, including ions at $m / z=219$ and 175 (Structures A1 and A2
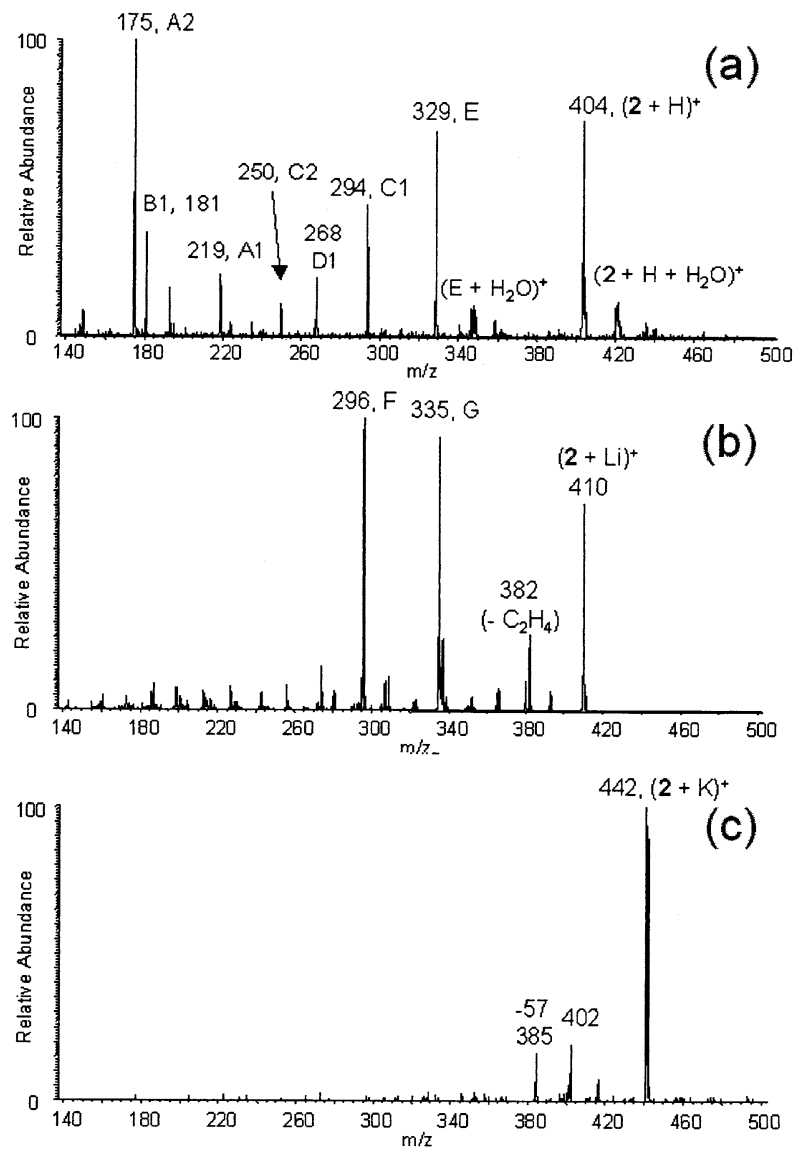

Figure 8. CAD mass spectra of complexes of LEA 2. (a) $(2+\mathrm{H})^{+}$; (b) $(2+\mathrm{Li})^{+}$; (c) $(2+\mathrm{K})^{+}$.

in Scheme 1) and ions at $m / z=181$ and 137 (Structures $\mathrm{B} 1$ and B2 in Scheme 1). Structures A1 and A2 and likewise $\mathrm{B} 1$ and $\mathrm{B} 2$ differ by a $\mathrm{C}_{2} \mathrm{H}_{4} \mathrm{O}$ unit, a common polyether subunit. These ions may cyclize and are characteristic of the benzo-crown ether skeletons of the lariat ethers. There are also common neutral losses for many of the protonated lariat ethers. Common losses include the elimination of 110 or $154 \mathrm{Da}(\mathrm{C} 1$ and $\mathrm{C} 2$, differing by a $\mathrm{C}_{2} \mathrm{H}_{4} \mathrm{O}$ unit) or loss of 136 or $180 \mathrm{Da}$ (D1 and D2, differing by a $\mathrm{C}_{2} \mathrm{H}_{4} \mathrm{O}$ unit). These neutral products are illustrated in Scheme $\mathbf{1}$ and involve elimination of a phenyl ring from the protonated lariat ether. The other major dissociation pathways involve loss of the pendant arm (Structure E in Scheme 1). Table 3 summarizes the occurrence of these various pathways for six of the protonated LEAs in addition to dibenzo16-crown-5. It is clear that there is a distribution of fragments involving loss of half of the dibenzo-16crown-5 macrocyclic skeleton in addition to those fragments that only involve loss of the pendant group or part of the pendant group.

The fragmentation patterns of both the $\mathrm{Li}^{+}$and $\mathrm{Na}^{+}$ complexes are generally similar for each lariat ether, so these will be discussed together. There are four pathways observed for the $\mathrm{Li}^{+}$complexes. One dominant process involves loss of the pendant arm(s) with the 

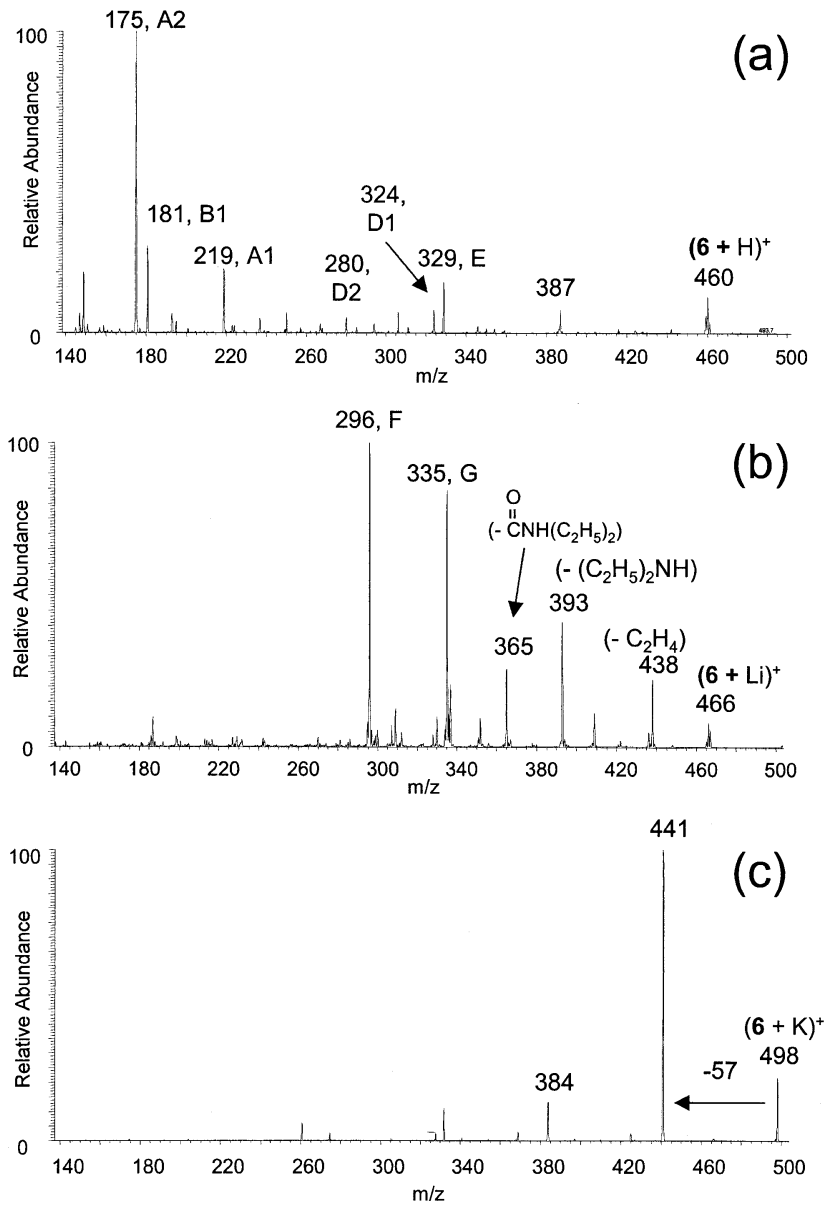

Figure 9. CAD mass spectra of complexes of LEA 6 . (a) $(6+$ $\mathrm{H})^{+} ;(\mathbf{b})(6+\mathrm{Li})^{+} ;(\mathbf{c})(\mathbf{6}+\mathrm{K})^{+}$.

propyl bridge of the crown ether ring, resulting in the intense product ion at $m / z 296$ for the $\mathrm{Li}^{+}$complexes in Figure $8 \mathrm{~b}, 9 \mathrm{~b}$, and $10 \mathrm{~b}$ (refer to Scheme 2). The second main process involves loss of just the amide pendant group, resulting in the product ion at $\mathrm{m} / \mathrm{z} 335$ in Figures $8 \mathrm{~b}$ and $9 \mathrm{~b}$ and the ion at $m / z 377$ in Figure $10 \mathrm{~b}$ for the propyl substituted lariat ether (Scheme 2). The loss of 28 $\mathrm{Da}$ is also consistently observed for the $\mathrm{Li}^{+}$and $\mathrm{Na}^{+}$ complexes (Figures $8 b$ and $9 b$ ). Based on MS/MS/MS experiments, this loss of $28 \mathrm{Da}$ was confirmed to be the elimination of $\mathrm{C}_{2} \mathrm{H}_{4}$, not the loss of $\mathrm{CO}$. For example, if the primary fragment ion at $m / z 438$ in Figure $9 \mathbf{b}$ is isolated and activated, this ion dissociates by loss of the entire amide substituent, thus confirming that the carbonyl group is still retained in the ion at $\mathrm{m} / \mathrm{z} 438$. The fourth common dissociation pathway of the $\mathrm{Li}^{+}$-cationized complexes involves the loss of $136 \mathrm{Da}$, which is attributed to the neutral loss D1 illustrated in Scheme $\mathbf{1 .}$ Most of the dominant fragmentation pathways for the $\mathrm{Li}^{+}$and $\mathrm{Na}^{+}$complexes involve loss of all or some portion of the pendant group, thus leading to product ions that are observed with significantly higher massto-charge ratios than those observed for the protonated lariat ethers. Pathways that involve cleavages of the macrocyclic skeleton (i.e., ones that produce fragment
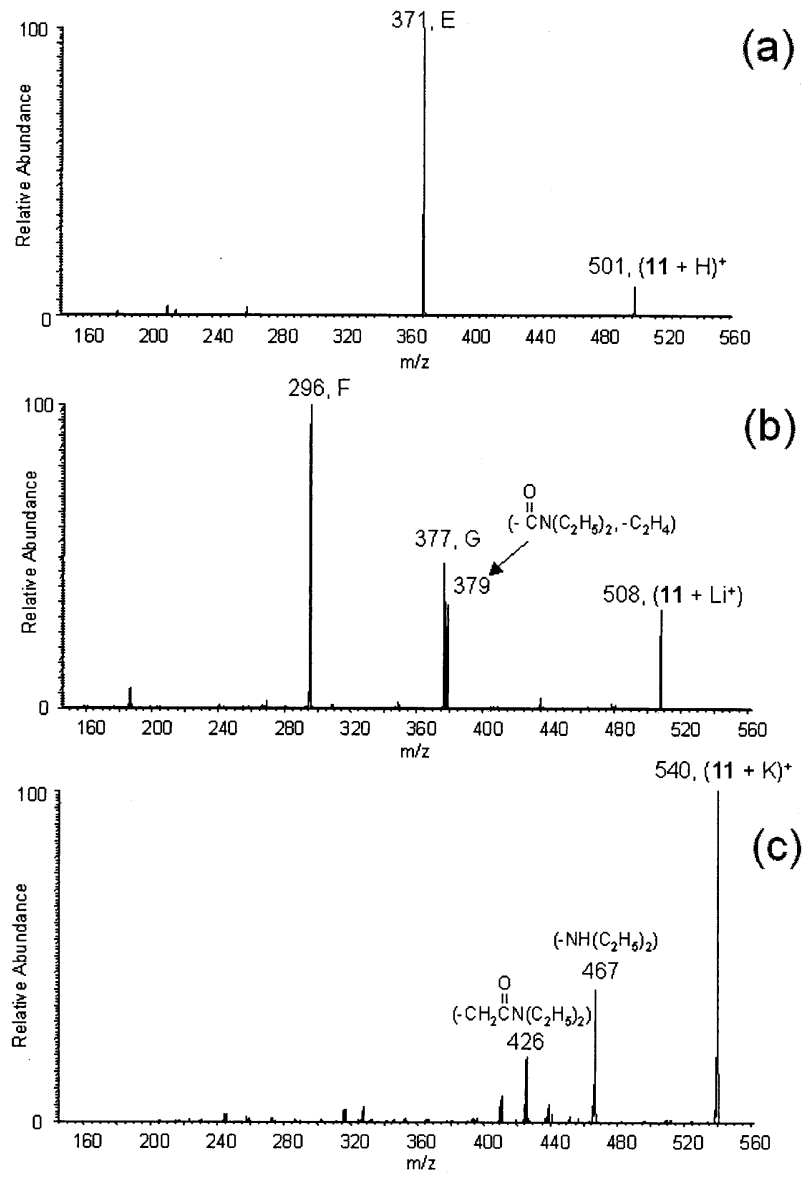

(c)

Figure 10. CAD mass spectra of complexes of LEA 11. (a) $(\mathbf{1 1}+$ $\mathrm{H})^{+}$; (b) $(\mathbf{1 1}+\mathrm{Li})^{+} ;(\mathbf{c})(\mathbf{1 1}+\mathrm{K})^{+}$.

ions at lower mass-to-charge values) are far less favorable than observed for the protonated lariat ethers.

The $\mathrm{K}^{+}$complexes generally do not dissociate by the same pathways seen for the protonated, $\mathrm{Li}^{+}$or $\mathrm{Na}^{+}$ complexes. In fact, the $\mathrm{K}^{+}$complexes for several of the LEAs and dibenzo-16-crown-5 dissociate predominantly by elimination of $\mathrm{K}^{+}$, resulting in no structurally diagnostic ions nor involving covalent bond cleavages of the macrocycle. This type of disassembly is characteristic of loosely bound noncovalent complexes in which the total energy of the macrocycle $/ \mathrm{K}^{+}$bonds is substantially lower than the energies of the covalent bonds of the macrocycle. For a few of the lariat ethers, namely $\mathbf{2}, \mathbf{6}, \mathbf{9}$, and $\mathbf{1 4}$, a common dissociation pathway is loss of $57 \mathrm{Da}$, presumably due to elimination of $\mathrm{C}_{3} \mathrm{H}_{5} \mathrm{O}$ from the macrocyclic skeleton (Scheme 2). This pathway is unlike any of those observed for the $\mathrm{Na}^{+}$ and $\mathrm{Li}^{+}$complexes and suggests that $\mathrm{K}^{+}$, when bound more strongly to the LEA, may be anchored to a different site than that of the smaller, more charge dense metal cations.

The $\mathrm{Rb}^{+}$and $\mathrm{Cs}^{+}$complexes generally dissociate solely by elimination of the metal cation. This fragmentation pathway is typical for weakly bound complexes.

In summary, the types of fragmentation patterns 
Table 3. CAD results for protonated dibenzo-16-crown-5 and LEAs (mol weight)

\begin{tabular}{|c|c|c|c|c|c|c|c|}
\hline \multirow[b]{2}{*}{ Fragment ion } & \multicolumn{7}{|c|}{ Relative intensity $^{a}$} \\
\hline & $\begin{array}{c}1 \\
(330)\end{array}$ & $\begin{array}{c}2 \\
(403)\end{array}$ & $\begin{array}{c}5 \\
(445) \\
\end{array}$ & $\begin{array}{c}6 \\
(459)\end{array}$ & $\begin{array}{c}9 \\
(473)\end{array}$ & $\begin{array}{c}11 \\
(501)\end{array}$ & $\begin{array}{c}14 \\
(543) \\
\end{array}$ \\
\hline $\mathrm{P}-\mathrm{H}_{2} \mathrm{O}^{\mathrm{b}}$ & + & & + & + & + & & \\
\hline $\mathrm{A} 1$ & & ++ & ++ & ++ & ++ & & ++ \\
\hline $\mathrm{A} 2$ & & +++ & +++ & +++ & +++ & & +++ \\
\hline B1 & +++ & ++ & +++ & ++ & +++ & + & ++ \\
\hline B2 & ++ & & & & & & \\
\hline$P-C 1$ & +++ & +++ & +++ & & ++ & & ++ \\
\hline$P-C 2$ & & ++ & ++ & & ++ & & ++ \\
\hline P - D1 & +++ & ++ & ++ & ++ & & ++ & \\
\hline$P$ - D2 & & & ++ & & ++ & & ++ \\
\hline E & & +++ & +++ & ++ & +++ & +++ & ++ \\
\hline
\end{tabular}

$\mathrm{a}_{++}=$dominant products with intensities that are $>50 \%$ of the base peak, $++=$ products with intensities that are $10-50 \%$ of the base peak, + $=$ low intensity products.

${ }^{\mathrm{b}} \mathrm{P}=$ protonated molecule.

observed vary dramatically for the protonated lariat ethers relative to the metal-cationized complexes. Fragmentation involving cleavages of the covalent bonds in the macrocyclic skeleton is much more pronounced for the protonated lariat ethers. The diverse array of fragmentation pathways for the protonated lariat ether suggests that the proton is mobile upon activation of the
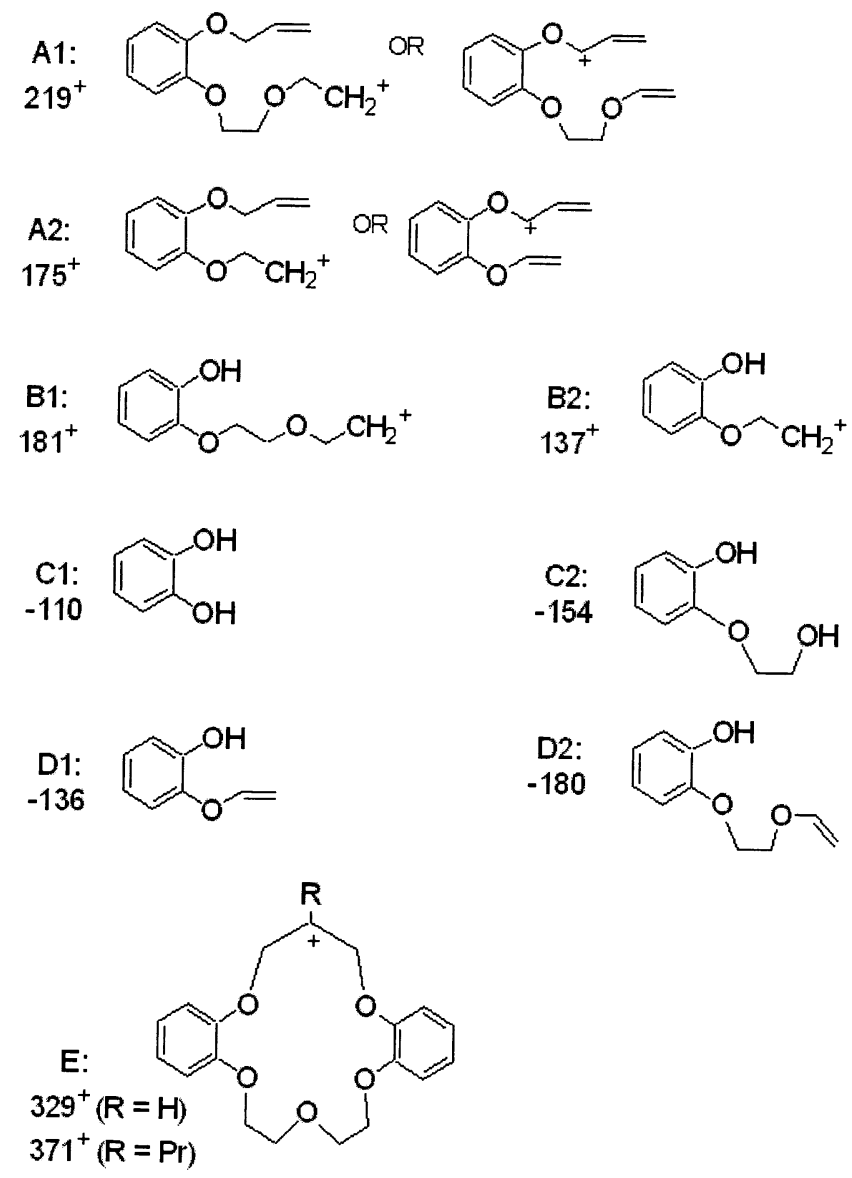

Scheme 1. Common product ions and neutral losses observed in the CAD mass spectra of protonated LEAs. complex or that the proton may initially be localized at several different sites prior to activation. The $\mathrm{Li}^{+}$and $\mathrm{Na}^{+}$complexes dissociate preferentially by elimination of the pendant groups, suggesting that the metal cation is nested in the cavity of the macrocycle. The complexes involving the larger alkali metal cations typically disassemble upon activation, implying weakly bound complexes.

\section{Conclusions}

In summary, the ESI-MS method proves to be an efficient way to evaluate the acid/base dependence of metal binding and to screen the alkaline earth metal cation selectivities of novel macrocyclic hosts, thus further extending the range of applications of the ESI-MS method for problems related to host-guest complexation and ligand selectivity. Dibenzo-16crown-5 lariat ethers with amide pendant arms show a

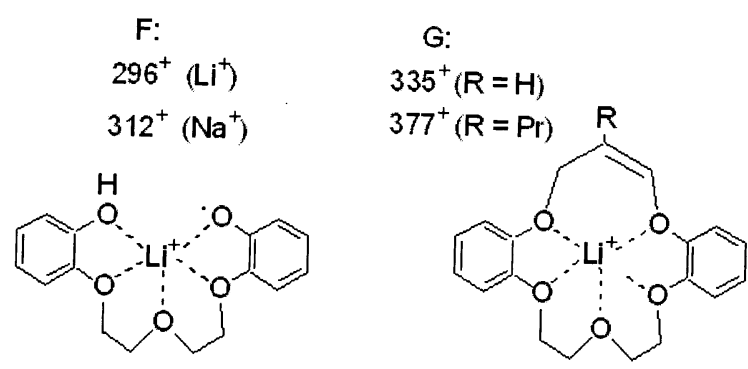

Loss of $57 \mathrm{Da}$ for $\mathrm{K}^{+}$complexes<smiles>[R]C1([R])COc2ccccc2OC12OCCO2</smiles>

Scheme 2. Predominant product ions observed in the CAD mass spectra of alkali metal complexes. 
selectivity order towards alkali metal cations of $\mathrm{Na}^{+}>$ $\mathrm{K}^{+}>\mathrm{Rb}^{+}>\mathrm{Cs}^{+}>\mathrm{Li}^{+}$, with relatively weak complexation of $\mathrm{Rb}^{+}, \mathrm{Cs}^{+}$, and $\mathrm{Li}^{+}$. Addition of an oxyacetamide group and a propyl group as geminal side arms on the dibenzo-16-crown-5 lariat ether framework enhances the $\mathrm{Na}^{+} / \mathrm{K}^{+}$selectivity in all cases, but the enhancement is greatest when the amide group is di-substituted with two methyl groups. Protonation of the amide nitrogen enhances the $\mathrm{Na}^{+} / \mathrm{K}^{+}$selectivity of the LEAs by up to an order of magnitude. This enhancement results from protonation of the amide nitrogen which precludes $\mathrm{Li}^{+}, \mathrm{K}^{+}$, or $\mathrm{Rb}^{+}$cation binding by the amide pendant group. The protonation electrostatically repels metal cations that do not nest as well as $\mathrm{Na}^{+}$in the dibenzo-16-crown-5 cavity, while only $\mathrm{Na}^{+}$can compete against protonation for complexation of the macrocycle.

Binding of $\mathrm{Ca}^{2+}$ over $\mathrm{Mg}^{2+}$ is favored by all the LEAs in methanol, as observed in the studies in aqueous solution conducted by Bartsch and coworkers [53]. $\mathrm{Ca}^{2+} / \mathrm{Mg}^{2+}$ selectivity generally increases with the increasing mass of the LEA, in contrast to the $\mathrm{Na}^{+} / \mathrm{K}^{+}$ selectivity. Also, $\mathrm{Ca}^{2+} / \mathrm{Mg}^{2+}$ selectivity is unaffected by the presence of a geminal propyl group on the LEAs.

$\mathrm{Li}^{+}$and $\mathrm{Na}^{+}$remain bound to the macrocyclic cavity upon activation of the complexes, while $\mathrm{K}^{+}$and larger alkali metal cations are mainly ejected during $\mathrm{CAD}$. The different fragmentation patterns observed for the protonated LEAs versus the $\mathrm{Li}^{+}$- and $\mathrm{Na}^{+}$-cationized LEAs supports different binding sites.

\section{Acknowledgments}

Funding for this work was provided by The Welch Foundation (grants F-1155 to JSB and D-775 to RAB) and the National Science Foundation (CHE-9820755).

\section{References}

1. Yamashita, M.; Fenn, J. B. Electrospray Ion Source. Another Variation on the Free-Jet Theme. J. Phys. Chem. 1984, 88, 4451-4459.

2. Fenn, J. B.; Mann, M.; Meng, C. K.; Wong, S. F.; Whitehouse, C. M. Electrospray Ionization-Principles and Practice. Mass Spectrom. Rev. 1990, 9, 37-70.

3. Smith, R. D.; Loo, J. A. Edmonds, C. G.,; Barinaga, C. J.; Udseth, H. R. New Developments in Biochemical Mass Spectrometry: Electrospray Ionization. Anal. Chem. 1990, 62, 882899.

4. Cole, R. B., Ed.; Electrospray Ionization Mass Spectrometry: Fundamentals, Instrumentation, and Applications. Wiley-Interscience: New York, NY, 1997, pp 1-577.

5. Veenstra, T. D. Electrospray Ionization Mass Spectrometry in the Study of Biomolecular Noncovalent Interactions. Biophys. Chem. 1999, 79, 63-79.

6. Loo, J. A. Electrospray Ionization Mass Spectrometry: A Technology for Studying Noncovalent Macromolecular Complexes. Int. J. Mass Spectrom. 2000, 200, 175-186.

7. Schalley, C. A. Supramolecular Chemistry Goes Gas Phase: The Mass Spectrometric Examination of Noncovalent Interactions in Host-Guest Chemistry and Molecular Recognition. Int. J. Mass Spectrom. 2002, 194, 11-39.
8. Loo, J. A.; Holsworth, D. D.; Root-Bernstein, R. S. Use of Electrospray Ionization Mass Spectrometry to Probe Antisense Peptide Interactions. Biol. Mass Spectrom. 1994, 23, 6-12.

9. Lamcharfi, E.; Chuilon, S.; Kerbal, A.; Kunesch, G.; Libot, F.; Virelizier, H. Electrospray Ionization Mass Spectrometry in Supramolecular Chemistry: Characterization of Noncovalent Cyclodextrin Complexes. J. Mass Spectrom. 1996, 31, 982-986.

10. Robinson, C. V.; Chung, E. W.; Kragelund, B. B.; Knudsen, J.; Aplin, R. T.; Doulsen, F. M.; Dobson, C. M. Probing the Nature of Noncovalent Interactions by Mass Spectrometry. A Study of Protein-CoA Ligand Binding and Assembly. J. Am. Chem. Soc. 1996, 118, 8646-8653.

11. Cheng, X.; Chen, R.; Bruce, J. E.; Schwartz, B. L.; Anderson, G. A.; Hofstadler, S. A.; Gale, D. C.; Smith, R. D. Using Electrospray Ionization FTICR Mass Spectrometry to Study Competitive Binding of Inhibitors to Carbonic Anhydrase. J. Am. Chem. Soc. 1995, 117, 8859-8860.

12. Cheng, Z. L.; Siu, K. W. M.; Guevremont, R.; Berman, S. S. Electrospray Mass Spectrometry: A Study on Some Aqueous Solutions of Metal Salts. J. Am. Soc. Mass Spectrom. 1992, 3, 281-288.

13. Chapeaurouge, A.; Bigler, L.; Shafer, A.; Bienz, S. Correlation of Stereoselectivity and Ion Response in Electrospray MassSpectrometry. Electrospray Ionization-Mass Spectrometry as a Tool to Predict Chemical Behavior? J. Am. Soc. Mass Spectrom. 1995, 6, 207-211.

14. Guevremont, R.; Siu, K. W. M. Le; Blanc, J. C. Y.; Berman, S. S. Are the Electrospray Mass Spectra of Proteins Related to Their Aqueous Solution Chemistry? J. Am. Soc. Mass Spectrom. 1992, 3, 216-224.

15. Wang, G.; Cole, R. B. Disparity Between Solution-Phase Equilibria and Charge State Distributions in Positive-Ion Electrospray Mass Spectrometry. Org. Mass Spectrom. 1994, 29, 419427.

16. Gokel, G. W.; Wang, K. Correlation of Solution and Gas Phase Complexation Assessed by Electrospray Ionization Mass Spectrometry: Application to One-, Two-, and Three-Ring Macrocycles. J. Org. Chem. 1996, 61, 4693-4697.

17. Leize, E.; Jaffrezic, A.; Van Dorsselaer, A. Correlation between Solvation Energies and Electrospray Mass Spectrometric Response Factors. Study by Electrospray Mass Spectrometry of Supramolecular Complexes in Thermodynamic Equilibrium in Solution. J. Mass. Spectrom. 1996, 31, 537-544.

18. Young, D-S.; Hung, H-Y.; Liu, L. K. An Easy and Rapid Method for Determination of Stability Constants by Electrospray Ionization Mass Spectrometry. J. Mass. Spectrom. 1997, 32, 432-437.

19. Hsieh, Y. L.; Li, Y.-T.; Henion, J. D.; Ganem, B. Studies of Noncovalent Interactions of Actinomycin D with SingleStranded Oligodeoxynucleotides by Ion Spray Mass Spectrometry and Tandem Mass Spectrometry. Biol. Mass Spectrom. 1994, 23, 272-276.

20. Cheng, X.; Chen, R.; Bruce, J. E.; Schwartz, B. L.; Anderson, G. A.; Hofstadler, S. A.; Gale, D. C.; Smith, R. D.; Gao, J.; Sigal, G. B.; Mammen, M.; Whitesides, G. M. Using Electrospray Ionization FTICR Mass Spectrometry to Study Competitive Binding of Inhibitors to Carbonic Anhydrase. J. Am. Chem. Soc. 1995, 117, 8859-8860.

21. Sannes-Lowery, K.A.; Hu, P.; Mack, D.P.; Mei, H.-Y.; Loo, J.A. HIV-1 Tat Peptide Binding to TAR RNA by Electrospray Ionization Mass Spectrometry. Anal.Chem. 1997, 69, 51305135.

22. Sannes-Lowery, K. A.; Mei, H.-Y.; Loo, J. A. Studying Aminoglycoside Antibiotic Binding to HIV-1 TAR RNA by Electrospray Ionization Mass Spectrometry. Int. J. Mass Spectrom. 1999, 193, 115-122. 
23. Wan, K. X.; Shibue, T.; Gross, M. L. Noncovalent Complexes between DNA-Binding Drugs and Double-Stranded Oligodeoxynucleotides: A Study by ESI Ion-Trap Mass Spectrometry. J. Am. Chem. Soc. 2000, 122, 300-307.

24. Blair, S. M.; Kempen, E. C.; Brodbelt, J. S. Determination of Binding Selectivities by ESI/Quadrupole Ion Trap Mass Spectrometry. J. Am. Soc. Mass Spectrom. 1998, 9, 1049-1059.

25. Blair, S. M.; Brodbelt, J. S.; Reddy, G. M.; Marchand, A. P. Evaluation of Binding Selectivities of Bis-Crowned Clefts by Electrospray Ionization/Quadrupole Ion Trap Mass Spectrometry. J. Mass Spectrom. 1998, 33, 721-728.

26. Kempen, E. C.; Brodbelt, J. S.; Bartsch, R. A.; Jang, Y.; Kim, J. S. Investigation of Alkali Metal Cation Selectivities of Lariat Ethers by Electrospray Ionization Mass Spectrometry. Anal. Chem. 1999, 71, 5493-5500.

27. Brodbelt, J.; Kempen, E.; Reyzer, M. Determination of Binding Selectivities by Electrospray Ionization Mass Spectrometry. Struct. Chem. 1999, 10, 213-220.

28. Blair, S. M.; Brodbelt, J. S.; Marchand, A. P.; Kumar, K. A.; Chong, H-S. Evaluation of Binding Selectivities of Caged Crown Ligands Towards Heavy Metals by Electrospray Ionization/Quadrupole Ion Trap Mass Spectrometry. Anal. Chem. 2000, 72, 2433-2445.

29. Goolsby, B.; Hall, B. J.; Brodbelt, J. S.; Adou, E.; Blanda, M. Determination of Alkali Metal Ion Binding Selectivities of Calixerenes by MALDI and ESI in a Quadrupole Ion Trap. Int. J. Mass Spectrom. 1999, 193, 197-204.

30. Blanda, M. T.; Farmer, D. B.; Brodbelt, J. S.; Goolsby, B. Synthesis and Alkali Metal Ion Binding Properties of Two Rigid Stereochemical Isomers of Calix[6]arene-Bis-Crown-4. J. Am. Chem. Soc. 2000, 122, 1486-1491.

31. Reyzer, M. L.; Brodbelt, J. S.; Marchand, A. P.; Chen, Z.; Huang, Z.; Namboothiri, I. N. N. Determination of Alkali Metal Binding Selectivities of Caged Crown Ligands by Electrospray Ionization Quadrupole Ion Trap Mass Spectrometry. Int. J. Mass Spectrom. 2001, 200, 57-69.

32. Blair, S.; Brodbelt, J.; Marchand, A.; Chong, H.-S.; Alidhodzic, S. Evaluation of Alkali Metal Binding Selectivities of Caged Aza-Crown Ligands by Electrospray Ionization Quadrupole Ion Trap Mass Spectrometry. J. Am. Soc. Mass Spectrom. 2000, 11, 884-891.

33. Williams, S.; Blair, S. M.; Brodbelt, J. S.; Huang, X.; Bartsch, R. A. Determination of Alkali Metal Cation Selectivities of Dibenzo-16-Crown-5 Lariat Ethers with Ether Pendant Groups using Electrospray Ionization Quadrupole Ion Trap Mass Spectrometry. Int. J. Mass Spectrom. 2001, 212, 389-401.

34. Williams, S. M.; Brodbelt, J. S.; Marchand, A. P.; Cal, D.; Mlinaric-Majerski, K. Metal Complexation of Novel ThiaCrown Ether Macrocycles by Electrospray Ionization Mass Spectrometry. Anal. Chem. 2002(17), 74, 4423-4433.

35. Kempen, E.; Brodbelt, J. A Novel Method for the Determination of Binding Constants by Electrospray Ionization Mass Spectrometry. Anal. Chem. 2000, 72, 5411-5416.

36. Lim, H.-K.; Hsieh, Y. L.; Ganem, B.; Henion, J. Recognition of Cell-Wall Peptide Ligands by Vancomycin Group Antibiotics: Studies Using Ion Spray Mass Spectrometry. J. Mass Spectrom. 1995, 30, 708-714.

37. Loo, J. A.; Hu, P.; McConnell, P.; Mueller, W. T.; Sawyer, T. K.; Thanabal, V. A Study of Src SH2 Domain Protein-Phosphopeptide Binding Interactions by Electrospray Ionization Mass Spectrometry. J. Am. Soc. Mass Spectrom. 1997, 8, 234243.

38. Young, D.-S.; Hung, H.-Y.; Liu, L. K. An Easy and Rapid Method for Determination of Stability Constants by Electrospray Ionization Mass Spectrometry. Rapid Commun. Mass Spectrom. 1997, 11, 769-773.
39. Jorgensen, T. J. D.; Roepstorff, P.; Heck, A. J. R. Direct Determination of Solution Binding Constants for Noncovalent Complexes between Bacterial Cell Wall Peptide Analogs and Vancomycin Group Antibiotics by Electrospray Ionization Mass Spectrometry. Anal. Chem. 1998, 70, 4427-4432.

40. Griffey, R. H.; Hofstadler, S. A.; Sannes-Lowery, K. A.; Ecker, D. J.; Crooke, S. T. Determinants of Aminoglycoside-Binding Specificity for rRNA by using Mass Spectrometry. Proc. Natl. Acad. Sci. U.S.A. 1999, 96, 10129-10133.

41. Martell, A. E.; Hancock, R. D. Metal Complexes in Aqueous Solutions. Plenum Press: New York, NY, 1996, Chapter VII.

42. Schalley, C. A. Supramolecular Chemistry Goes Gas Phase: The Mass Spectrometric Examination Of Noncovalent Interactions in Host-Guest Chemistry and Molecular Recognition. Int. J. Mass Spectrom. 2000, 194, 11-39.

43. Schalley, C. A. Molecular Recognition and Supramolecular Chemistry in the Gas Phase. Mass Spectrom. Rev. 2001, 20, 253-309.

44. Shannon, R. D. Revised Effective Ionic Radii and Systematic Studies of Interatomic Distances in Halides and Chalcogenides. Acta Crystallogr. A Found. Crystallogr. 1976, 32, 751767.

45. Bartsch, R. A.; Lu, J.; Ohki, A. Potentiometric Selectivities of Dibenzo-16-Crown-5 Compounds for Alkali and Alkaline Earth Metal Cations and Ammonium Ions. J. Incl. Phenom. Mol. Recog. Chem. 1998, 32, 133-150.

46. Armentrout, P. B. Cation-Ether Complexes in the Gas Phase: Thermodynamic Insight into Molecular Recognition. Int. J. Mass Spectrom. 1999, 193, 227-240.

47. Nicoll, J. B.; Dearden, D. V. Reactions of Multidentate Ligands with Ligated Alkali Cation Complexes: Self-Exchange and "Sandwich" Complex Formation Kinetics of Gas Phase Crown Ether-Alkali Cation Complexes. Int. J. Mass Spectrom. 2001, 204, 171-183.

48. Dearden, D. V.; Liang, Y.; Nicoll, J. B.; Kellersberger, K. A. Study of Gas-Phase Molecular Recognition using Fourier Transform Ion Cyclotron Resonance Mass Spectrometry (FTICR/MS). J. Mass Spectrom. 2001, 36, 989-997.

49. Ohki, A. Lu., J.-P.;; Huang, X.; Bartsch, R. A. Alkali Metal, Alkaline Earth Metal, and Ammonium Ion Selectivities of Dibenzo-16-Crown-5 Compounds with Functional Side Arms in Ion-Selective Electrodes. Anal. Chem. 1994, 66, 4332-4336.

50. Ohki, A.; Lu, J.-P.; Hallman, J. L.; Huang, X.; Bartsch, J. A. Sodium Ion-Selective Electrodes Based on Dibenzo-16crown-5 Compounds with Pendent Ester Groups. Anal. Chem. 1995, 67, 2405-2408.

51. Ohki, A.; Lu, J.-P.; Bartsch, R. A. Effect of Side-Arm Variation in Dibenzo-16-crown-5 Compounds on the Potentiometric Selectivity for Sodium Ion. Anal. Chem. 1994, 66, 651-654.

52. Ohki, A.; Lu, J.-P.; Maeda, S.; Bartsch, R. A. Sodium IonSelective Electrodes Based on Dibenzo-16-crown-5 Compounds with Pendent Amide Groups. Anal. Chem. 1994, 66, 1743-1746.

53. Ohki, A.; Iwaki, K.; Naka, K.; Maeda, S.; Collier, J. J.; Jang, Y.; Hwang, H-.S.; Bartsch, R. A. Comparison Of Dibenzo-16Crown-5 Compounds with Pendent Amide Groups as Sodium Ionophores in Ion-Selective Electrodes and in Solvent Extraction. Electroanalysis 1996, 8, 615-618.

54. Ohki, A.; Iwaki, K.; Naka, K.; Kamata, S.; Maeda, S.; Lu, J.-P.; Bartsch, R. A. Sodium Ion Sensors Based on Dibenzo-16Crown-5 Compounds with Amide Side Arms. Supramol. Chem. 1996, 6, 391-394.

55. Recommendations for Nomenclature of Ion-Selective Electrodes. IUPAC Analytical Chemistry Division, UK. Pure Appl. Chem. 1976, 48, 127-132. 
56. Van Berkel, G. J.; Glish, G. L.; McLuckey, S. A. Electrospray Ionization Combined with Ion Trap Mass Spectrometry. Anal. Chem. 1990, 62, 1284-1285.

57. Pederson, C. J. Cyclic Polyethers and Their Complexes with Metal Salts. J. Am. Chem. Soc. 1967, 89, 7017-7036.

58. Kasprzyk, S. P.; Bartsch, R. A. Synthesis of Dibenzocrown Ethers with Pendant Amide Groups. J. Heterocyclic Chem. 1993, 30, 119-123.

59. Izatt, R. M.; Pawlak, K.; Bradshaw, J. S.; Bruening, R. L. Thermodynamic and Kinetic Data for Macrocycle Interactions with Cations and Anions. Chem. Rev. 1991, 91, 1721-2085.

60. Zhou, S.; Edwards, A. G.; Cook, K. D.; Van Berkel, G. J. Investigation of the Electrospray Plume by Laser-Induced Fluorescence Spectroscopy. Anal. Chem. 1999, 71, 769-776.

61. Wang, H.; Agnes, G. R. Kinetically Labile Equilibrium Shifts Induced by the Electrospray Process. Anal. Chem. 1999, 71, $4166-4172$.
62. Mansoori, B. A.; Volmer, D. A.; Boyd, R. K. Wrong-WayRound Electrospray Ionization of Amino Acids. Rapid Commun. Mass Spectrom. 1997, 11, 1120-1130.

63. Zhou, S.; Cook, K. D. Protonation in Electrospray Mass Spectrometry: Wrong-Way-Round or Right-Way-Round? J. Am. Soc. Mass Spectrom. 2000, 11, 961-966.

64. Easterly, C. E.; Hercules, D. M.; Houalla, M. Electrospray-Ionization Time-of-Flight Mass Spectrometry: $\mathrm{pH}$-Dependence of Phosphomolybdate Species. Appl. Spectrosc. 2001, 55, 1671-1675.

65. Julian, R. R.; Beauchamp, J. L. Site Specific Sequestering and Stabilization of Charge in Peptides by Supramolecular Adduct Formation with 18-Crown-6 Ether by Way of Electrospray Ionization. Int. J. Mass Spectrom. 2001, 210/211, 613-623.

66. Sutrisno Baran, Y.; Lawrance, G. A.; von Nagy-Felsobuki, E. I. Determination of Acid Dissociation Constants of Neamine by Potentiometric and Electrospray Mass Spectral Techniques. Struct. Chem. 2001, 12(2), 189-195. 